\title{
Phylogeny of the Southwest Asian Pimpinella and related genera based on nuclear and plastid sequences
}

\author{
S. Fereidounfar ${ }^{1}$, F. Ghahremaninejad ${ }^{1}$ and M. Khajehpiri ${ }^{2}$ \\ ${ }^{1}$ Department of Plant Sciences, Faculty of Biological Sciences, \\ Kharazmi University, Tehran, Iran \\ ${ }^{2}$ Department of Biology, Faculty of Sciences, University of Isfahan, Isfahan, Iran \\ Corresponding authors: S. Fereidounfar / F. Ghahremaninejad \\ E-mail: std_Fereidounfar@khu.ac.ir/ghahremaninejad@khu.ac.ir \\ Genet. Mol. Res. 15 (4): gmr15048767 \\ Received May 6, 2016 \\ Accepted June 27, 2016 \\ Published October 24, 2016 \\ DOI http://dx.doi.org/10.4238/gmr15048767
}

Copyright (C) 2016 The Authors. This is an open-access article distributed under the terms of the Creative Commons Attribution ShareAlike (CC BY-SA) 4.0 License.

ABSTRACT. Pimpinella L. is a large genus and arguably one of the
most complex genera in the family Apiaceae. In this study, the infra-
generic relationship between Southwest Asian Pimpinella species and
their generic allies in the tribe Pimpinelleae Spreng were investigated
using sequence data from the cpDNA (chloroplast DNA) rps 16 exon
and rpL16 intron and nuclear ribosomal DNA internal transcribed spacer
regions. In total, 185 accessions representing 52 species of Pimpinella,
8 species of Aegopodium, and the monotypic Opsicarpium Mozaff.
were analyzed using maximum parsimony and Bayesian methods. In
our phylogenetic study, Pimpinella and Opsicarpium were considered
together as a monophyletic group within the tribe Pimpinelleae. As a
result, Opsicarpium insignis Mozaff has been formally transferred to
Pimpinella. Our results indicate that the genera Pimpinella and Reutera
Boiss formed a monophyletic group and also supported merging the 
genus Reutera with Pimpinella. This study confirms the transfer of the Southwest Asian Pimpinella anthriscoides (Boiss.) F. Ghahrem., Khajepiri \& Mozaff to the genus Aegopodium as Aegopodium tribracteolatum Schmalh.

Key words: cpDNA rps 16 exon; cpDNA rpL16 intron; nrDNA ITS; Phylogeny; Pimpinella; Umbelliferae

\section{INTRODUCTION}

Downie et al. (2010) provided a general phylogenetic framework within the subfamily Apioideae based on the phylogenetic analysis of nrDNA internal transcribed spacer (ITS) sequences. These analyses revealed the evolutionary relationships of many genera and clades of this subfamily more clearly compared to a pre-existing phylogenetic classification for the group based on the methods used by Downie et al. (2001).

According to Downie et al. (2010), the Pimpinelleae tribe is recognized as a paraphyletic or polyphyletic group within Apioideae. This is because the main species-rich genus in this tribe, Pimpinella, is also assigned to a minimum of seven other major clades of this subfamily.

The genus Pimpinella is one of the largest genera of the subfamily Apioideae within Apiaceae, with approximately 150 species distributed in Asia, Europe, and Africa. A few species can also be found in South America and one can be found in the western part of North America (Pimenov and Leonov, 1993).

The derived conditions (traits) of the family in which Pimpinella is included are: generally herbaceous habit; presence of compound leaves; small and inconspicuous flowers, with few floral parts arranged in whorls and grouped in umbel-shaped inflorescences as the result of prolonged co-evolution with insects. The presence of inferior ovaries composed of sealed carpels is a further indication of the degree of evolution. All Pimpinella species can be annual, biennial, or perennial and are generally characterized by the presence of fibrous collars on the top of the rootstock and compound umbels. These plants usually grow on dry rocky places, rocky crevices, fields, meadows, mountain pastures, and grasslands (Engstrand, 1987; Velayos, 2003).

In the genus Pimpinella, the basic chromosome number is $\mathrm{x}=8$ to 11 . Some variations in ploidy level are exhibited in this genus $(2 n=2 x=18$ and $2 n=4 x=36)$. In addition, some aneuploid species have been recorded (Constance et al., 1976; Daushkevich et al., 1995; Shner et al., 2004; Ghahremaninejad et al., 2013).

In some cases, intraspecies and even intrapopulation variation has been found in the ploidy level (Rostovtseva, 1982; De Montmollin, 1986; Ghahremaninejad et al., 2013). Many Pimpinella species are narrowly distributed and habitat-specific (Mozaffarian, 2007). Therefore, this indicates that the process of speciation in this genus is tightly associated with polyploidy and adaptation, and the evolutionary history of Pimpinella is not been well understood. Marked variations in the Pimpinella genus include fruit shape (ovoid-oblong to elliptic), fruit surface (glabrous to tuberous hair), fruit anatomy, leaf division, flowers and inflorescences, which result in the recognition of numerous and often hardly discernible taxa (Engstrand, 1987; Matthews, 1972). Basal leaves and mature fruits are two important factors required for accurate identification; however, they are associated with some limitations. For

Genetics and Molecular Research 15 (4): gmr15048767 
example, the previous fruits on the plant are usually dried out whereas the next are not yet fully ripe; in addition, only lateral divisions of the basal leaves are preserved. Therefore, it is not surprising that both the infrageneric classification and the phylogenetic position of Pimpinella remain disputed.

Pimpinella is traditionally classified in the tribe Apieae (Pimenov and Leonov, 1993). De Candole (1827) divided the genus Pimpinella into three sections: Tragoselinum, characterized by its glabrous fruits and perennial roots; Tragium, with hairy fruits, perennial (rarely biennial) roots, and pinnate to bipinnatus radical leaves with ovate segments; and Anisum, which included species with down-covered annual fruits. One of the most important reviews was that of Bentham and Hooker (1867), who included 65-70 species under the name Pimpinella, classified into six sections according to the habitat of the plant, leaf and fruit morphology, and petal color.

In 1875, Boissier named specimens with emarginate or bilobate petals as Pimpinella. That author recognized two sections within Pimpinella, $P$ sect Tragium Spreng and sect Tragoselinum Tourn distinguished by pubescent versus glabrous fruit. However, it was not until 1910, when Wolff used petal color, morphology, and indumentums of fruits to undertake a thorough taxonomic revision, that the status of the genus was somewhat clarified. The only taxonomic analysis covering all species in the genus is that of Wolff (19100, who divided the genus into three sections: Reutera, including species with yellow flowers and glabrous or hairy fruits; Tragium, generally with white flowers and bristly or hairy fruits, granular or tubercle, sometimes nearly glabrous or almost completely smooth; and Tragoselinum, also with white flowers and glabrous or totally glabrous fruits. Wolff (1927) reduced the genus Reutera to section rank within the genus Pimpinella as sect. Reutera. Recent phylogenetic analyses strongly suggest that the infrageneric classification of Pimpinella proposed by Wolff (1910) does not correspond to any of the recovered clades, and as such, it is clearly artificial. Engstrand (1987), in his treatment of species from the Iranian plateau, did not propose any infrageneric classifications for the 25 species of the area. He recorded 19 species of Pimpinella in the flora of Iran. Recent taxonomic studies on representatives of the Iranian Pimpinella revealed some new species. Today, about 22 species are generally recognized in the flora of Iran (Mozaffarian, 2007). While Ghahremaninejad and Khajepiri (2010) separated Pimpinella anthriscoides Boiss into the monotypic genus Pseudopimpinella based on fruit anatomical characters, both molecular analysis and morphological data support merging P. anthriscoides with the genus Aegopodium as A. tribracteolatum Schmalh. (Zakharova et al., 2012).

Matthews (1972) recognized 23 species of Pimpinella in the flora of Turkey, without sectional affiliations. The Pimpinella species of China have been divided into two groups: P. sect. Tragium (Spreng.) DC., containing those species with hairy, or distinctly roughened fruits and obsolete calyx teeth, and P. sect. Tragoselinum (Miller) DC., containing those species with glabrous fruits and obsolete or conspicuous calyx teeth ( $\mathrm{Pu}$ and Watson, 2005).

Pimpinella has been rarely studied from a morphological or phytochemical viewpoint (Baser et al., 1996; Khajepiri et al., 2010). The most comprehensive phytochemical analysis of the genus was published by Tabanca et al. (2005), who also described the phylogenetic relationships among species.

Similar to the most traditional identifying of higher level taxa within Apiaceae, molecular systematic studies have revealed that the genus Pimpinella is polyphyletic, and taxonomic delimitation of the genus has not yet been resolved (Downie and Katz-Downie, 1999; Zhou et al., 2008, 2009; Downie et al., 2010). A recent molecular phylogenetic study

Genetics and Molecular Research 15 (4): gmr15048767 
of Pimpinella clearly showed it to be a non-monophyletic taxon (Downie et al., 2010; Wang et al., 2014). Yet the monophyly of a Pimpinella 'core group' in the tribe Pimpinelleae is strongly supported (Magee et al., 2010; Wang et al., 2014). Most and the African and Malagasy Pimpinella species are placed with their Eurasian counterparts in Pimpinelleae (Magee et al., 2010; Wang et al., 2014). Chromosome base number was found to be consistent with the groupings recovered in the molecular analyses (Magee et al., 2010; Wang et al., 2014).

African and Malagasy Pimpinella species with a chromosome base number of $\mathrm{x}=11$ form the earliest diverging clade. The remaining African species ally with several Eurasian species of Pimpinella and share a chromosome base number of $\mathrm{x}=9$ (Magee et al., 2010).

Spalik and Downie (2006) showed that the African members of tribe Pimpinelleae form a monophyletic branch derived from a common ancestor of Middle Eastern origin. Recent molecular studies have suggested a close affinity between the newly described genus Opsicarpium and Pimpinella (Valiejo-Roman et al., 2006a; Wang et al., 2014).

To date, relatively few molecular systematic studies have included substantial sampling of Pimpinella across its distributional range, and no published study has included most of the species of Pimpinella from Southwest Asia. Therefore, the present study was carried out to: 1) investigate the relationships between and generic allies in the tribe Pimpinelleae for a broader analysis of Pimpinella evolution; 2) evaluate the monophyly of Opsicarpium and Reutera with respect to other genera in the tribe Pimpinelleae; and 3) detect polyploidy events in Pimpinella for the first time.

To achieve those objectives, we conducted a phylogenetic study using DNA sequences of the nuclear ribosomal ITS and two chloroplast DNA (cpDNA) loci (rps16 exon and rpL16 intron), because numerous studies incorporating Pimpinella and some of its putative allies have demonstrated the utility of these loci in resolving intra and intergeneric relationships within Apiaceae (Spalik and Downie, 2007; Downie et al., 2001, 2010; Wang et al., 2014).

\section{MATERIAL AND METHODS}

A total of 31 new sequences consisting of 15 nuclear ribosomal ITS sequences and 16 cpDNA loci sequences (rps16 and rpL16) were generated for this study. Leaf material for DNA extraction was obtained primarily from herbarium specimens (TARI, Research Institute of Forests and Rangelands, Iran; Kharazmi University; Yüzüncü Yil University, Turkey). Through fieldwork in Iran. In total, 14 species of Pimpinella were selected to more completely represent the morphological range of the genus in West Asia. Multiple accessions were sampled for Aegopodium tribracteolatum Schmalh, and Pimpinella corymbosa Boiss, Pimpinella eriocarpa Banks \& Sol, Pimpinella kotschyana Boiss, Pimpinella peucedanifolia Fischer ex Ledeb, Pimpinella puberula (DC.) Boiss, Pimpinella saxifrage L., and Pimpinella tragium subsp lithophila (Schischk). Tutin to assess possible infraspecific variation in these widespread species.

Furthermore, an accession of the Iranian endemic species Opsicarpium insignis was included to estimate the systematic position. Taxa, voucher information, and GenBank accession Nos. for all rps16, rpL 16 and ITS are listed in the Table S1.

We performed a BLAST search in GenBank to detect all genera that have close affinities to species that are currently classified in Pimpinella. In this way, some representatives of the tribes Pimpinelleae Spreng., Komarovieae J. Zhou \& S.R. Downie, Oenantheae Dumort, Pleurospermeae M.F. Watson \& S.R. Downie, Selineae Spreng., and of the Acronema clade

Genetics and Molecular Research 15 (4): gmr15048767 
according to the classification by Downie et al. (2010) were also added. All newly obtained sequences have been deposited in GenBank.

As outgroups, we included representatives of closely related genera of the Apioideae tribe Pyramidoptereae Boiss. (Bunium luristanicum Rech.f.) and two distantly related genera of the Apioideae tribe Tordylieae W.D.J. Koch (Heracleum persicum Desf., Zosima absinthifolia Link) based on previous phylogenetic studies of the subfamily Apioideae (Downie et al., 2010). The final sampling included 115 accessions of 112 species from 37 genera for large ITS, and 85 accessions of 46 species from 25 genera for a concatenated data matrix (see Table S1).

\section{DNA extraction, amplification, and sequencing}

Total genomic DNA was isolated from 12-22 mg dried leaf tissues using a DNeasy Plant Mini Kit (Qiagen, Valencia, CA, USA).

Nuclear and plastid regions were amplified using specific primers and PCR conditions were as follows (Table 1). The ITS region of nrDNA was amplified using the primers ITS $_{4}$ and $\mathrm{ITS}_{5}$. The thermal reactions were initiated for $1 \mathrm{~min} 30 \mathrm{~s}$ at $94^{\circ} \mathrm{C}$ to ensure denaturation of double-stranded template DNA, followed by 34 cycles with the following cycling profile: 1 min at $94^{\circ} \mathrm{C}$ (denaturation), $1 \mathrm{~min}$ at $53^{\circ} \mathrm{C}$ (annealing), and $1 \mathrm{~min}$ at $72^{\circ} \mathrm{C}$. This was followed by a final extension of $10 \mathrm{~min}$ at $72^{\circ} \mathrm{C}$. Amplification of chloroplast regions of rps 16 and $\mathrm{rpL} 16$ was performed using the primers rps16 F and Exon-CR for rps16 and rpl16, and R1516 for rpL 16. The same thermal cycling profile was used for both chloroplast primers as follows: 3 min at $94^{\circ} \mathrm{C}$ to ensure denaturation of double-stranded template DNA, followed by 30 cycles with the following cycling profile: $1 \mathrm{~min}$ at $94^{\circ} \mathrm{C}$ (denaturation), $1 \mathrm{~min}$ at $55^{\circ} \mathrm{C}$ (annealing), and $2 \mathrm{~min}$ at $72^{\circ} \mathrm{C}$. This was followed by a final extension of $7 \mathrm{~min}$ at $72^{\circ} \mathrm{C}$. PCR products were purified with Escherichia coli exonuclease I and Fast AP Thermo sensitive Alkaline Phosphatase (Fermentas, St. Leon-Rot, Germany) following the manufacturer recommendations. Cycle sequencing reactions were performed using the purified PCR product, AmpliTaq DNA polymerase (Roche Molecular Systems, Alameda, CA, USA), and fluorescent Big Dye terminators (Applied Biosystems, Foster City, CA, USA). The products were resolved by electrophoresis using an ABI 377A automated DNA sequencer (Applied Biosystems). The resulting chromatograms were analyzed using the program ChromasPro 1.41 (TechnelysiumPty Ltd., Australia).

Table 1. Primers used for PCR and sequencing.

\begin{tabular}{l|l|c|l|c}
\hline Region & Name & F/R & Sequence $\left(5^{\prime}-3^{\prime}\right)$ & Mode \\
\hline \multirow{2}{*}{ ITS } & $\mathrm{ITS}_{4}$ & $\mathrm{~F}$ & TCCTCCGCTTATTGATATGC & $\mathrm{P}, \mathrm{S}$ \\
\cline { 2 - 5 } & $\mathrm{ITS}_{5}$ & $\mathrm{R}$ & GGAAGTAAAAGTCGTAACAAGG & $\mathrm{P}$ \\
\hline \multirow{2}{*}{$r p s$} & $\mathrm{rps} 16 \mathrm{~F}$ & $\mathrm{~F}$ & TTTGAAACGATGTGGTAGA & $\mathrm{P}, \mathrm{S}$ \\
\cline { 2 - 5 } & Exon CR & $\mathrm{R}$ & ACCCACGTTGCGAAGAT & $\mathrm{P}, \mathrm{S}$ \\
\cline { 2 - 5 }$r p L$ & rp116 & $\mathrm{F}$ & GCTATGCTTAGTGTGTGACTCGTTG & $\mathrm{P}, \mathrm{S}$ \\
\cline { 2 - 5 } & R1516 & $\mathrm{R}$ & CCCTTCATTCTTCCTCTAYGTTG & $\mathrm{P}$ \\
\hline
\end{tabular}

$\mathrm{F} / \mathrm{R}$, forward and reverse, respectively. Mode refers to PCR amplification (P) and sequencing (S).

\section{Sequence and phylogenetic analyses}

Nucleotide sequences of the four data matrices [large ITS, reduced ITS, cpDNA ( $r p s 16$ exon plus rpl16 intron), and concatenated (reduced ITS and cpDNA)] were each aligned 
initially using MUSCLE (Edgar, 2004) with default parameters for gap penalty and extension. The alignment was then edited where necessary using Mesquite version 1.12 (Maddison and Maddison, 2001). Indels were coded as independent, single, binary characters following the methodology of Simmons and Ochoterena (2000) and appended to the sequence matrix for phylogenetic analysis.

Three data matrices including those for the large ITS, reduced ITS and cpDNA (rps16 exon plus rpl16 intron), were used for phylogenetic analyses of the individual loci. The large ITS data matrix included representatives of all genera detected as close affinities to species currently classified in the genus Pimpinella (Zhou et al., 2009; Wang et al., 2014). We generated a reduced ITS data matrix, which included those species with cpDNA sequence information available in GenBank. For the concatenated data, only reduced ITS and cpDNA (rps 16 exon plus rpl16 intron) data were applied. Congruence in the phylogenetic signal of the reduced ITS and cpDNA data sets was examined by a visual comparison of tree topologies and branch support, and a partition homogeneity (or ILD) test was performed with PAUP* 4.0b10 (Farris et al., 1994; Swofford, 2002) using a heuristic search with 1000 replicates, a maximum tree limit of 1000, and tree-bisection-reconnection (TBR) branch swapping. Sequence divergence was calculated using the Kimura two parameter distance model (Kimura, 1980). Phylogenetic analyses included the Bayesian inference (BI) method using MrBayes ver. 3.1 (Ronquist and Huelsenbeck, 2003), and maximum parsimony (MP) and maximum likelihood (ML) methods implemented using PAUP* ver. 4.0b10 (Swofford, 2002). MP and BI analyses were conducted on both separate and combined (total evidence analysis) datasets. For MP analysis, heuristic searches were performed with 1000 random stepwise addition replicates and TBR branch swapping using the MULTREES option. In order to prevent PAUP* from crashing, the options CHUCK and CHUCKSCORE were used. The substitution model for the Bayesian analysis was selected using the program model test ver. 3.6 (Posada and Crandall, 1998) and the Akaike information criterion. The analyses were carried out for 5,000,000 generations with four Monte Carlo Markov Chains initiated and a sampling frequency of 100 generations. The initial 10,000 saved trees were discarded, and the consensus and posterior probabilities (PP) of particular clades were calculated based on the remaining trees. Following completion, sampled trees were plotted against their likelihood in order to recognize the point where the likelihoods converged on a maximum value, and all trees prior to this convergence were discarded as the "burn-in" phase. The remaining trees were combined in a majority rule consensus.

\section{Hypothesis testing and alternative topology}

We used the SH test (Shimodaira and Hasegawa, 1999) to compare the best ML trees recovered from analyses of the combined molecular data with the constraint topologies based on existing hypotheses of the monophyly of the genus Opsicarpium constructed in Treeview version 1.6.6 (RDM. Page, 2001). The trees were loaded as a backbone into PAUP*. Heuristic searches were conducted using the outlined ML parameters to find the shortest trees compatible with the constraint. The likelihood score for the best ML tree was then compared with the score of the best ML tree using one-tailed non-parametric SH tests. The SH test, which was performed on the combined data set to test the monophyly of the genus Opsicarpium, is significantly favored over the phylogenetic hypothesis suggested by other evidence.

Genetics and Molecular Research 15 (4): gmr15048767 


\section{RESULTS}

\section{Comparison of the divergence and phylogenetic utility of chloroplast and nuclear DNA data sets}

The main characteristics of the large ITS, reduced ITS, cpDNA, and combined data sets, along with the corresponding tree statistics, are summarized in Table 2.

Table 2. Data set and tree statistics from separate and combined analyses of the nuclear and two chloroplast regions.

\begin{tabular}{|c|c|c|c|c|}
\hline & Large ITS & Reduced ITS & $\begin{array}{c}\text { cpDNA } \\
(r p l 16 \text { intron }+r p s 16)\end{array}$ & $\begin{array}{c}\text { Combined } \\
\text { (reduced ITS + cpDNA) }\end{array}$ \\
\hline Number of sequences & 115 & 24 & 24 & 24 \\
\hline Length range & $530-610$ & $535-650$ & $1520-1670$ & $2055-2320$ \\
\hline Aligned length (including informative indels) & 661 & 657 & 2110 & 2767 \\
\hline GC content mean $(\%)$ - ingroup & 35.1 & 45.6 & 23.1 & 29.9 \\
\hline GC content mean $(\%)$ - outgroup included & 34.6 & 45.5 & 23.3 & 29.8 \\
\hline Sequence divergence $(\%)$ - ingroup & $0.10-23.5$ & $0.00-21.54$ & $0.00-27.73$ & $0.00-16.24$ \\
\hline Sequence divergence (\%) - outgroup included & $1.12-25$ & $0.00-23.14$ & $4.76-32.12$ & $5.79-35.55$ \\
\hline Number of variable sites - ingroup & 123 & 59 & 251 & 345 \\
\hline Number of variable sites - outgroup included & 117 & 146 & 232 & 378 \\
\hline Potentially informative characters - ingroup (\%) & 400 & 121 & 198 & 294 \\
\hline Potentially informative characters - outgroup (\%) & 415 & 124 & 107 & 231 \\
\hline Number of unambiguously coded indels & 7 & 3 & 2 & 11 \\
\hline Coded indel size range & $2-6$ & $2-4$ & $1-3$ & $2-5$ \\
\hline of MPTs & 0.83 & 0.88 & 0.84 & 0.81 \\
\hline CI of MPTs (excluding uninformative characters) & 0.72 & 0.71 & 0.71 & 0.71 \\
\hline of MPTs & 0.78 & 0.84 & 0.85 & 0.78 \\
\hline Number of MPTs & 100 & 3 & 1500 & 9 \\
\hline Length of MPTs & 2235 & 402 & 157 & 848 \\
\hline
\end{tabular}

$\mathrm{CI}=$ consistency index $; \mathrm{RI}=$ retention index $; \mathrm{MPTs}=$ most-parsimonious trees.

The combined cpDNA data set contained 2110 characters, of which 251 were variable and showed the lowest percentage of informative characters $(5.07 \%)$, whereas nrDNA sequences contained 657 characters, of which 59 were variable and showed the highest percentage of informative characters $(18.8 \%)$.

The combined cpDNA sequences were 1.26-times more variable than the average in-group pairwise divergence, and 3.7-times less variable than the reduced nrDNA sequences with regard to the absolute number of informative characters. Therefore, the use of the ITS sequences seemed to be an appropriate strategy for phylogenetic reconstruction in terms of the number of informative characters.

Genetic distances between reduced ITS sequences in the sample were computed using Kimura's two-parameter model (Table 2) and ranged from 0.0014 to 0.2154 among the species of Pimpinella, and from 0.0021 to 0.2314 between taxa of Pimpinella and other genera in the tribe Pimpinelleae. No infraspecific variation in the ITS sequences was found in the two accessions of $P$. eriocarpa and $P$. kotschyana, whereas the accessions of A. tribracteolatum, and $P$. corymbosa, $P$. peucedanifolia, $P$. puberula, $P$. saxifrage, and $P$. tragium subsp lithophila exhibited a distance of 0.01488 to 0.09407 .

\section{Phylogenetic analyses}

\section{Large ITS sequence analyses}

Two large ITS methods of phylogenetic reconstruction produced congruent trees

Genetics and Molecular Research 15 (4): gmr15048767 
without any major differences; therefore, Figure 1 shows the BI tree with the addition of the parsimony bootstrap percentages.

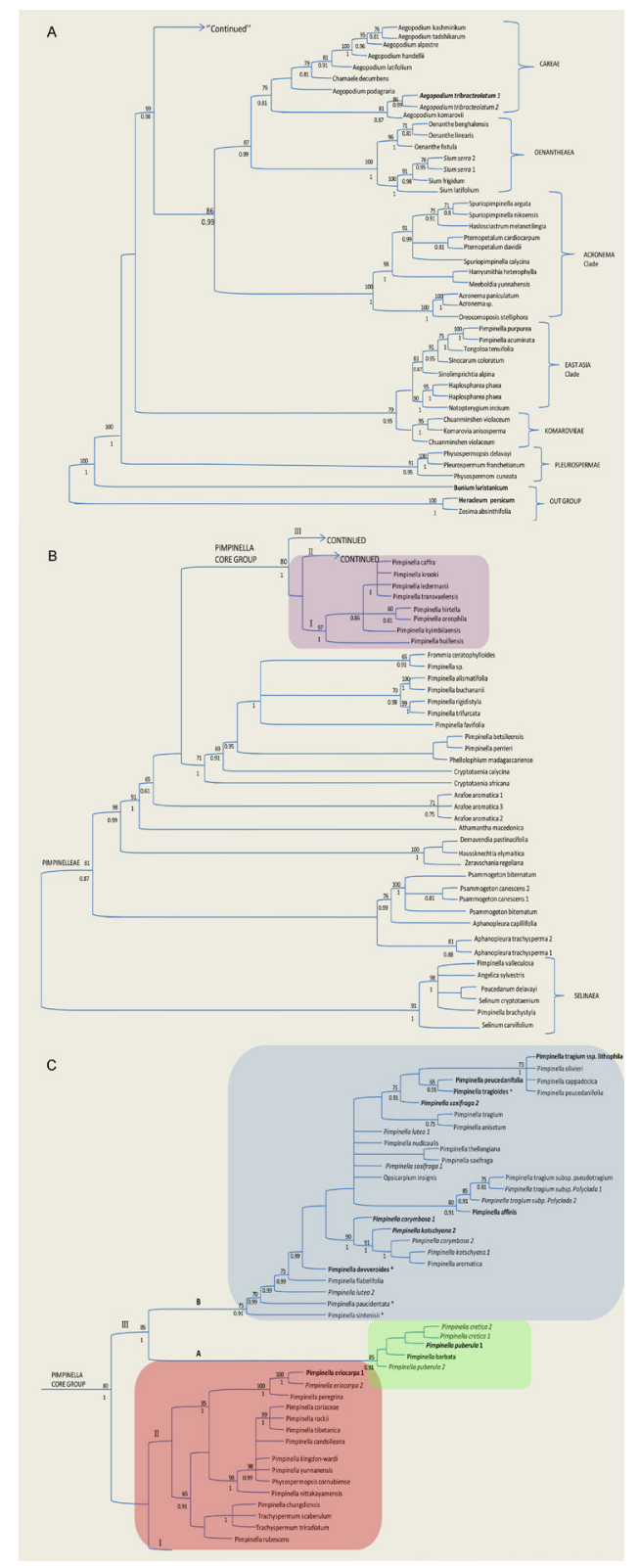

Figure 1. Bayesian majority-rule consensus tree derived from the large ITS dataset. Posterior probability and bootstrap support values are shown on the branches. The species involved in this study are boldfaced. The species with more than one accession are indicated by numbers. Species names in bold and italics indicate that those species were involved in this study and that the accessions were obtained from GenBank, respectively. Asterisks indicate species that are confirmed as Reutera group.

Genetics and Molecular Research 15 (4): gmr15048767 
The monophyly of Pimpinella is not supported statistically by the large ITS data sets. Parsimony analysis recovered a topology that is consistent with that of Wang et al. (2014). There are six clades and three subclades of "major importance" discussed by those authors on our cladogram. The following tribes were strongly supported by ITS sequences: the Pimpinelleae $(\mathrm{PP}=0.87, \mathrm{BS}=81 \%)$, Selineae $(\mathrm{PP}=1.00, \mathrm{BS}=91 \%)$, Oenantheae (PP $=1.00, \mathrm{BS}=100 \%)$, and Komarovieae $(\mathrm{PP}=0.95, \mathrm{BS}=79 \%)$, and the Acronema $(\mathrm{PP}=$ $1.00, \mathrm{BS}=100 \%)$ and East Asia $(\mathrm{PP}=0.97, \mathrm{BS}=75 \%)$ clades, and Pimpinella 'core group' comprising three subclades, subclade I $(\mathrm{PP}=1.00, \mathrm{BS}=97 \%)$, subclade II $(\mathrm{PP}=0.87, \mathrm{BS}=$ $74 \%)$, and subclade III ( $\mathrm{PP}=1.00, \mathrm{BS}=85 \%)$.

In the BI tree (Figure 1), all West Asian Pimpinella species fell into the Pimpinella 'core group', which were mostly in subclade III $(\mathrm{PP}=1.00, \mathrm{BS}=85 \%)$. Taxa in subclade III shared a primarily Eurasian distribution; however, relationships within this subclade were largely unresolved. Within subclade III, we identified two additional major subgroups, termed subgroup A and B (Figure 1).

\section{DNA combined analysis}

In total, 48 accessions representing 41 taxa were used in the phylogenetic analyses of combined data [reduced ITS and cpDNA (rps16 exon plus rpll6 intron)]. Separate analyses of each cpDNA and nuclear DNA region were shown to be significantly incongruent according to the ILD test $(\mathrm{P}<0.01)$. However, results from each individual analysis did not show any incongruence supported by BP. Because no hard incongruence was found, the inclusion of all DNA regions in a single analysis should maximize the explanatory power regardless of the level of character incongruence between data sets detected with the ILD (Hipp et al., 2004). When each data set was analyzed separately (data not shown), the results were similar to those obtained by the combined analyses, but both BP and resolution were greater in the combined analysis. Statistics for all single and combined analyses are given in Table 2. The BI trees resulting from analyses of the combined data matrices are presented in Figure 2. In general, relationships common to the $\mathrm{BI}$ tree derived from the large ITS dataset with overlapping taxon sets were found in the combined data set BI tree (Figures 1 and 2). Although the BI tree of the combined analysis offered greater resolution of relationships than the BI tree of the large ITS dataset, a high level of congruence was apparent between them, with many nodes supported by high PP and BS support values, That is, two major groups found in previous phylogenetic studies (Wang et al., 2014) were recovered (subclade II, subclade III) within the Pimpinella core group. While subclade II encompassed two species of Chinese Trachyspermum and $P$. eriocarpa, which is an annual species widespread in Southwest Asia, subclade III comprised almost all annual and perennial Eurasian species of Pimpinella and the Iranian endemic species $O$. insignis.

Within subclade III, we identified two additional major subgroups (A and B) comprising species distributed in Europe, and Western, Central, and Southern Asia. However, some differences in relationships can be observed in the relative positions of the Acronema cade and tribe Oenantheae, which were placed as a sister group to the remaining clades (Figure 2).

Genetics and Molecular Research 15 (4): gmr15048767 


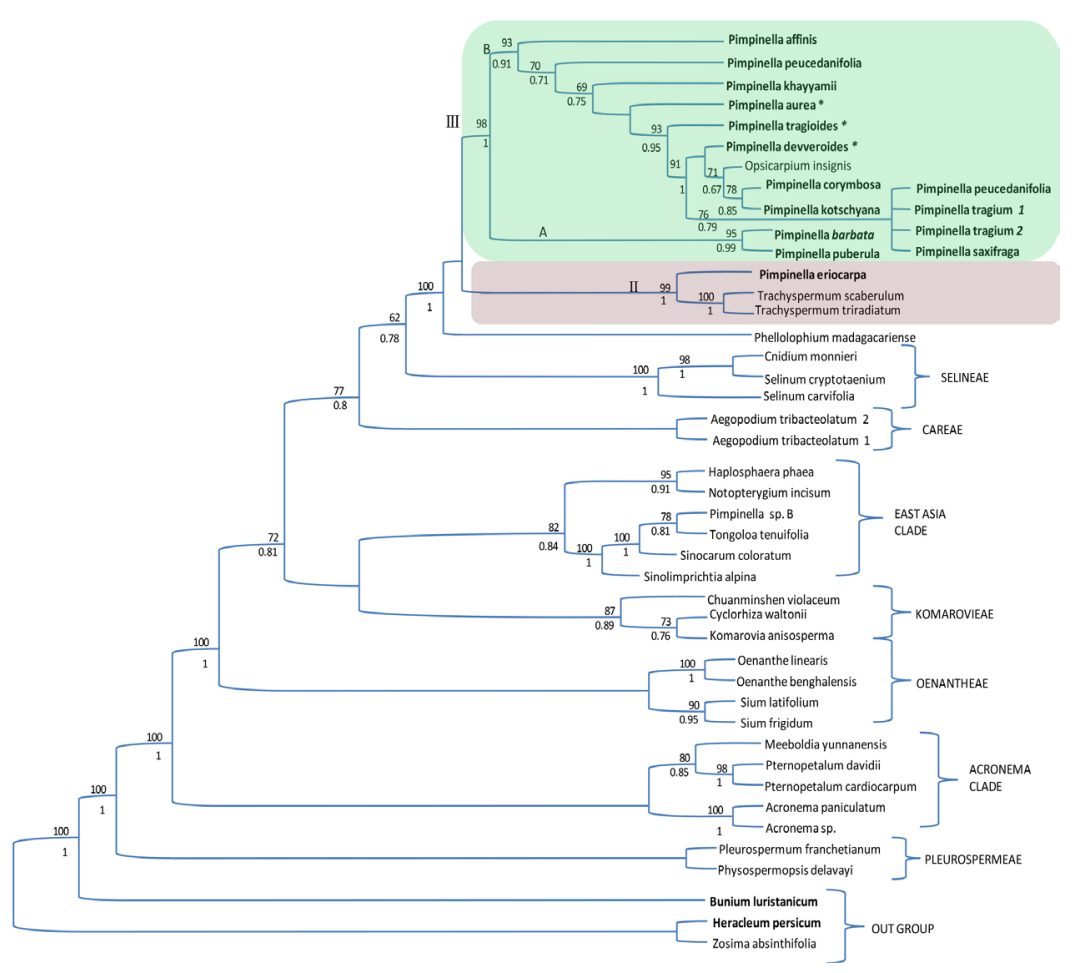

Figure 2. Bayesian majority-rule consensus trees derived from reduced ITS and cpDNA datasets. Posterior probability and bootstrap support values are shown on branches. The species involved in this study are boldfaced; the accessions which are obtained from GenBank are indicated in normal text. Bold and italic indicate species with multiple accessions. Asterisks indicate species that are confirmed as Reutera group.

\section{DISCUSSION}

The phylogenetic trees developed in the present study are compatible with the division of Apioideae proposed by Downie et al. (2010) and Zhou et al. (2009), and with the results of previous investigations on Pimpinelleae (Wang et al., 2014). Our discussion of the phylogenetic relationships in subclades I and II of the Pimpinella core group was based on the large ITS dataset BI tree, which included more representative sampling (Figure 1), with emphasis on Southwest Asian species.

\section{Phylogenetic placement of Pimpinella species}

Phylogenetic reconstructions using three different data sets consistently showed that Pimpinella is polyphyletic with the majority of its members contained within the Pimpinella core group with two major well-supported subclades (II, III; Figure 2).

The affinity of some members of Pimpinella with the tribes Oenantheae, Selineae, and the clades Acronema and East Asia, and the polyphyly of the genus, were inferred in earlier phylogenetic studies (Figure 1) (Downie and Katz-Downie, 1996; Zhou et al., 2008, 2009; Downie et al., 2010; Magee et al., 2010; Wang et al., 2014). 
Consistent with previous data (Magee et al., 2010; Wang et al., 2014), a close correlation was observed between geography and the phylogenetic tree in our analysis (Figure 1). Within the Pimpinella core group, all of the African species of Pimpinella constituted an early diverging branch and formed a sister group to Eurasian Pimpinella. It has been suggested that southern Africa is the origin of the predominantly herbaceous Apiaceae subfamily Apioideae, and that the woody habit is plesiomorphic (Downie and Katz-Downie, 1999). Those species share a chromosome base number of $\mathrm{x}=9$ for many species. The subclades (II and III) identified are consistent with those previously reported (Magee et al., 2010; Wang et al., 2014). All species of Pimpinella from Southwest Asia fall within subclades II and III, which show affinity to other Pimpinella species. Based on molecular evidence within the context of the genus Pimpinella, Wang et al. (2014) placed some Chinese species in four other tribes within the subfamily (Figure 1).

Interspecific relationships within subclade II were well resolved and strongly supported ( $\mathrm{BS}=85 \%, \mathrm{PP}=93$ ) (Figure 1). Two more clades were present, one comprising $P$. eriocarpa and $P$. peregrina in the large ITS dataset BI tree (Figure 1), and one comprising P. eriocarpa in the BI tree of the combined analysis (Figure 2) with a wide distribution in Eurasia, sharing the chromosome base number of $\mathrm{x}=8$ (Al-Eisawi, 1989; Pimenov et al., 1996). Another clade was represented by all species native to China and shared a chromosome base number of $x=9$. An anatomical character possibly associated with the results of the molecular phylogenies is the number of vallecular vittae between each rib. Based on the fruit anatomy, P. eriocarpa can be distinguished from other Southwest Asian Pimpinella by the presence of two vallecular vittae between each rib, while most of the Southwest Asian species have more than four vallecular vittae between the ribs (Khajepiri et al., 2010).

Subclade III encompasses species with a wide distribution in Eurasia, and is divided into two major subgroups (A and B). P. barbata (DC.) Boiss., P. puberula and P. cretica Poir formed subgroup A and occupy a basal position in subclade III of both trees (Figures 1 and 2). In addition to the molecular support, the relationship between $P$. barbata, $P$. puberula, and $P$. cretica is strongly supported by several morphological characters, including pubescent annual herb, cauline leaf with linear lobe, white petal, and depressed stylopodium. P. cretica differs from $P$. puberula by being glabrous or sometimes minutely puberulent, with glabrous rays, and fruit minutely setulose.

Subgroup B contained all other taxa insubclade III $(\mathrm{BS}=75 \%$, PP $=0.91)$. This subgroup was resolved by the combined large ITS dataset (Figures 1 and 2).

The basal portion of subgroup B in the large ITS dataset BI tree was a ladder composed of P. sintenisii H. Wolff., P. paucidentata V.A. Matthews, P. lutea Desf., P. flabellifolia (Boiss.) Benth. ex Drud, and $P$. deverroides Boiss. (Figure 1). This relationship was strongly supported by morphology; however, these species are very similar and are described as perennial herbs with yellow, not emarginated, and acute apex petals, and simple, oblong, or cylindrical basal leaves (Matthews, 1972). They show a wide distribution from Lebanon, extending into Turkey. The remaining Pimpinella species and the monotypic genus, $O$. insignis form a strongly supported clade (Figure 1, PP $=0.99$ ). Most of the relationships in this clade are unresolved. This clade consists of two well-supported groups (Figure 1) in the molecular analysis. In one of those groups, one accession of $P$. corymbosa was sister to all members of the clade (Figure 1, BS $=90 \%, \mathrm{PP}=1$ ) and the other accession of $P$. corymbosa is the sister taxon to one accession of $P$. kotschyana and $P$. aromatica (Figure 1, BS =91, PP =1). This relationship is strongly supported by morphology, and these species are very similar with the exception 
of $P$. kotschyana, which differs from P. corymbosa with the presence of 1.5-4.0-cm long leaf segments, umbels with 10-22 rayes, and fruit with very long dense hairs (Matthews, 1972).

\section{Polyploidy in the evolution of Pimpinella}

Magee et al. (2010) reported the chromosome numbers of $2 n=18,20$ for Eurasian Pimpinella. The most common base chromosome number is $\mathrm{x}=10$. Numerous cases of aneuploidy and polyploidy have been recorded for this genus (Ghahremaninejad et al., 2013; Shner et al., 2004). However, chromosome number alone has limited taxonomic value, because high levels of variation in infraspecific chromosome number have been noted for some species (Ghahremaninejad et al., 2013; Shner et al., 2004). Hybridization, while relatively rare in Apiaceae, has been reported in Heracleum (Logacheva et al., 2008).

The diploid $P$. flabellifolia may have been involved in the origin of the polyploidy in $P$. deverroides (Figure 1). These species are morphologically very similar, but the diploid taxa can be distinguished from the polyploid taxa by the presence of fewer umbel rays and flowers (Engstrand, 1987; Mozaffarian, 2007). Western Eurasian P. deverroides and P. flabellifolia are very narrow endemic species occurring in western Iran and southern Turkey.

\section{Taxonomic implications}

\section{Pimpinella tragium Vill.}

P. tragium Vill. is a perennial plant widely distributed across Europe, Asia, and North Africa (Matthews, 1972; Engstrand, 1987). Morphological variability and density of leaf indumentum, as well as leaf incision and geographical pattern of those morphological characters along the whole geographic area of the $P$. tragium, make the taxonomy of the $P$. tragium group difficult.

The species $P$. tragium is divided into five subspecies: P. tragium subsp lithophila (Schischk.) Tutin, P. tragium Vill. subsp polyclada (Boiss. \& Heldr.) Tutin, P. tragium Vill. subsp pseudotragium (DC.) Matthews, and P. tragium subsp depressa (DC.) Tutin. P. tragium subsp titanophila (Woronow) Tutin differs in leaf shape and structure, life history, and development (Matthews, 1972; Engstrand, 1987).

Recently, Yurtseva and Tikhomirov (1998) reassessed the classification of P. tragium. They believed that the recognition of infraspecific taxa is impractical and can misrepresent the complicated pattern of morphological variability within $P$. tragium. Those authors suggested that $P$. tragium subsp lithophila and some other subspecific taxa (P. tragium subsp depressa and $P$. tragium subsp titanophila) should be included in this group under the name $P$. tragium, and suggested that $P$. tragium subsp. Polyclada should be treated at the specific level as $P$. polyclada Boiss. et Heldr.

From a morphological point of view, P. tragium subsp lithophila has smaller leaf lobes, which are 5-10 (12)-mm long with a deeply serrate margin, while $P$. tragium subsp polyclada has bigger leaf lobes, which are 10-15 (20)-mm long and a margin that is not deeply serrate (Matevski, 2005).

The phylogenetic analysis united $P$. affinis with the two sampled subspecies of $P$. tragium [P. tragium subsp Polyclada and P. tragium subsp pseudotragium (DC.) Mathews], which received strong support while nested deeply within subgroup B. P. tragium subsp lithophila (Schischk.) Tutin, and the group of five species from Southwest Asia, constituted 
an unresolved polytomy; these findings showed that the group of tragium subspecies was not monophyletic (Figure 1). The sister-group relationship between P. tragium subsp polyclada and $P$. tragium subsp pseudotragium reflected high sequence variation among subspecies within the tragium group, and confirms that the two subspecies share a common ancestor and carry the same genome. Non monophyly of the tragium subspecies group is not surprising, because from a morphological point of view, P. tragium subsp lithophila has smaller leaf lobes, which are 5-10 (12)-mm long with a deeply serrate margin, while P. tragium subsp polyclada has bigger leaf lobes at 10-15 (20)-mm long, and a margin that is not deeply serrate (Matevski, 2005).

The present data suggested that the character "length and margin of leaf lobe color" can be considered reliable for assessing phylogenetic relationships within the tragium subspecies group. This finding is inconsistent with those of Yurtseva and Tikhomirov (1998).

\section{Opsicarpium Mozaff.}

Traditionally, genera are delimited on the basis of morphological distance rather than phylogeny. However, morphological differences between two groups of closely related species, or putative genera, do not necessarily imply that they constitute sister lineages. Rather, one is nested within the other, with the former being defined based on synapomorphies and the latter on symplesiomorphies (Kurzyna-Młynik et al., 2008). The genus Opsicarpium, and several other segregates of Pimpinella, illustrated this taxonomic practice.

The current phylogenetic analyses strongly suggested that Opsicarpium is nested within Pimpinella, specifically among the taxa of subclade III (Figure 1 and 2). Opsicarpium consists of one narrowly distributed and endemic species, O. insignis Mozaff., which occurs in the northern and middle Zagros Mountains of Iran (Mozaffarian, 2007). The generic status of the monotypic Opsicarpium is accepted (Valiejo-Roman et al., 2006a; Wang et al., 2014) because of the close relationship with Pimpinella. Morphologically, Opsicarpium is similar to Pimpinella for fruit structures (Khajepiri et al., 2010) and pinnate leaves. Compared with Pimpinella, Opsicarpium has no or only highly reduced sepals (versus reduced sepals in Pimpinella). The most significant difference between Opsicarpium and Pimpinella was thought to be the possession of a terminal segment roughly circular in Opsicarpium versus a terminal segment that is roughly linear in Pimpinella (Mozaffarian, 2007).

Our phylogenetic trees were consistent with those previously reported (ValiejoRoman et al., 2006a; Wang et al., 2014) such that Opsicarpium and Pimpinella are considered together as a monophyletic group within Pimpinelleae (Figure 1 and 2). The secure placement of Opsicarpium within Pimpinella is also strongly supported by our data, where Pimpinella is considered to be monophyletic requires eight more steps, and topology of Pimpinella to be monophyletic have lower likelihood value (one-tailed SH test; $\mathrm{P}=0.016$ ). Hence, our results suggest that Opsicarpium should be included in Pimpinella. This conclusion is also supported by similarities in fibrous collar, pinnate leaves, compound umbel inflorescence, bracts and bracteoles, fruit structure (numerous vittae) and variable commissural vittae (2-8) shared by several species of Pimpinella (Khajepiri et al., 2010). Therefore, the new synonym and the necessary combination are proposed here.

Pimpinella insignis (Mozaff.) Fereid., comb. nov.

Opsicarpium insignis Mozaff. in Botanich. Zhurn 88, 2: 89 (2003). Type: [Iran],

Genetics and Molecular Research 15 (4): gmr15048767 
Kordestan, Bane, ca. $10 \mathrm{~km}$ on the road from Sute to Sonnateh to Saghez, after hajiMohammadan, 1950-2150 m. 17.08. 1991. V. Mozaffarian, 70103 (holotype: TARI).

\section{A. tribracteolatum}

A. tribracteolatum was described initially under Pimpinella, as $P$. anthriscoides Boiss. This perennial species is distributed in southwest and central Asia and possesses 1-2-pinnate basal leaves and glabrous fruit (Boissier, 1872). Aegopodium L., a genus in Careae tribe, used to contain seven perennial species distributed in the Palearctic (Europe, temperate Asia, North Africa, adventives in North America). Aegopodium is characterized by several synapomorphies: glabrous fruits without prominent ribs; inconspicuous vallecular and commissural vittae, sometimes invisible in mature fruits (3-5 in each furrow and 4-9 on the commissural side); big, slightly lignified endocarp cells and a broad ultimate leaf (Zakharova et al., 2012).

Recently, molecular studies grouped $P$. anthriscoides with species of Aegopodium based on nuclear region ITS DNA (Zakharova et al., 2012). Consequently, Zakharova et al. (2012) transferred P. anthriscoides to Aegopodium, as A. tribracteolatum, which is the nomenclature adopted here. On the basis of the results of a fruit anatomical study, Ghahremaninejad et al. (2010) transferred $P$. anthriscoides to the monotypic genus Pseudopimpinella.

The placement of $A$. tribracteolatum within Aegopodium is also strongly supported here. In both ITS and combined plastid trees, this is nested in a group with Aegopodium and Careae (Figure 1 and 2). The strongly supported position of this species in the Aegopodium group confirms that the submersion of $P$. anthriscoides into Aegopodium by Zakharova et al. (2012) was correct. This conclusion is also supported by the clear morphological similarity in glabrous fruits shared by several species of Aegopodium (Khajepiri et al., 2010). In IPNI (http://www.ipni.org), Pseudopimpinella is mentioned as a valid taxon name. Thus here, we synonymize this taxon with Aegopodium:

\section{Aegopodium L. Sp. Pl. 1: 265.1753}

Pseudopimpinella F. Ghahrem., Khajepiri \& Mozaff., Flora, Morphol. Distrib. Funct. Ecol. Pl. 205(5): 353. 2010.

Aegopodium tribracteolatum Schmalh. Bull. Soc. Geogr. Cauc. (1892) 22; et in Ber. Deutsch. Bot. Ges. x. (1892) 289. Morphol.

Pseudopimpinella anthriscoides (Boiss.) F. Ghahrem., Khajepiri \& Mozaff., Flora,

Distrib. Funct. Ecol. Pl. 205(5): 353. 2010.

P. anthriscoides Boiss. Fl. Orient. [Boissier] 2: 874. [Dec 1872 or Jan 1873].

\section{Reutera Boiss.}

Pimpinella was established by Linnaeus (1753) in Species Plantarum, which consists of plants with bisexual flowers with five stamens and two carpels. In 1875, Boissier named specimens with entire petals as Reutera Boiss. and specimens with emarginate or bilobate petals as Pimpinella.

In the most comprehensive classification of Pimpinella, based mainly on morphological 
characters, Wolff (1910) treated Reutera as a section of Pimpinella. This view was dismissed by subsequent systematic studies, which proposed no infrageneric classification for the genus (Engstrand, 1987; Matthews, 1972). The results of recent phylogenetic analyses strongly suggested that the infrageneric classification of Pimpinella as proposed by Wolff (1910) does not correspond to any of the clades recovered and is thus clearly artificial (Magee et al., 2010).

Of approximately 150 Pimpinella species, five were placed in the genus Reutera according to Boissier (1875). Reutera is recognized by the unique character of the petal, which has an entire or yellow petal at the rank of genus and section, respectively (Boissier, 1875; Wolff, 1910). However, when the presence of the entire petal trait is mapped onto the tree, it appears to be homoplastic in Pimpinella (Figure 1, character 1,2), indicating that these characters are of limited phylogenetic value and that Wolff's submersion of Reutera into Pimpinella was correct. The phylogenies presented here show that the genus defined by Boissier (1875) is paraphyletic. Our molecular data unambiguously support the circumscription of Pimpinella by Wolff (1910); however, recognition of Reutera as a section of Pimpinella proposed by Wolff (1910) is not supported.

\section{Conflicts of interest}

The authors declare no conflict of interest.

\section{ACKNOWLEDGMENTS}

Researvh supported by the Iran National Science Foundation: INSF (Project \#93046704 to Farrokh Ghahremaninejad). We gratefully acknowledge support from T, TARI, and VANF herbaria for permitting the removal of leaf material for DNA extraction.

\section{REFERENCES}

Al-Eisawi DMH (1989). Chromosome counts of Umbelliferae of Jordan. Ann. Bot. (Lond.) 47: 201-214.

Baser KHC, Özek T, Duman H and Güner A (1996). Essential oil of Pimpinella aromatica Bieb. from Turkey. J. Essent. Oil Res. 8: 463-464. http://dx.doi.org/10.1080/10412905.1996.9700667

Bentham $\mathrm{G}$ and Hooker JD (1867). Umbelliferae. Genera plantarum, 1: 859-931.

Boissier E (1875). Flora Orientalis: Calyciflorae gamopetalae (Vol. 3). apud H. Georg.

Boissier E (1872). Umbelliferae. Flora Orientalis 2: 819-1090.

Constance L, Chuang TI and Bell CR (1976). Chromosome numbers in Umbelliferae. V. Am. J. Bot. 1: 608-625. http:// dx.doi.org/10.2307/2441824

Daushkevich JV, Alexeeva TV and Pimenov MG (1995). IOPB chromosome data 10. Int. Organ. Pl. Biosyst. Newslett. 25: 7-8.

De Candole AP (1827). Dictionnaire classique d'histoire naturelle11. Rey et Gravier, Libraries-Editeurs (Ed.) 406.

De Montmollin B (1986). Etude cytotaxonomique de la flore de la Crète. III: Nombres chromosomiques. Candollea (Geneve) 41: 431-439.

Downie SR and Katz-Downie DS (1996). A molecular phylogeny of Apiaceae subfamily Apioideae: evidence from nuclear ribosomal DNA internal transcribed spacer sequences. Am. J. Bot. 83: 234-251. http://dx.doi.org/10.2307/2445943

Downie SR and Katz-Downie DS (1999). Phylogenetic analysis of chloroplast rps 16 intron sequences reveals relationships within the woody southern African Apiaceae subfamily Apioideae. Can. J. Bot. 77: 1120-1135. http://dx.doi. org/10.1139/b99-086

Downie SR, Plunkett GM, Watson MF, Spalik K, et al. (2001). Tribes and clades within Apiaceae subfamily Apioideae: the contribution of molecular data. Edinb. J. Bot. 58: 301-330. http://dx.doi.org/10.1017/S0960428601000658

Downie SR, Spalik K, Katz-Downie DS and Reduron JP (2010). Major clades within Apiaceae subfamily Apioideae

Genetics and Molecular Research 15 (4): gmr15048767 
as inferred by phylogenetic analysis of nrDNA ITS sequences. Plant Divers. Evol. 128: 111-136. http://dx.doi. org/10.1127/1869-6155/2010/0128-0005

Edgar RC (2004). MUSCLE: a multiple sequence alignment method with reduced time and space complexity. $B M C$ Bioinformatics 5: 113. http://dx.doi.org/10.1186/1471-2105-5-113

Engstrand L (1987). PimpinellaL. In: Flora des Iranischen Hochlandes und der Umrahmenden Gebirge, no: 162 (Rechinger KH, eds.). Graz: Akademische Druck-u, Verlagsanstalt. 311-333.

Farris JS, Källersjö M, Kluge AG and Bult C (1994). Testing significance of incongruence. Cladistics 10: 315-319. http:// dx.doi.org/10.1111/j.1096-0031.1994.tb00181.x

Ghahremaninejad F and Khajepiri M (2010). Transferring Pimpinella anthriscoides var. cruciata to genus Pseudopimpinella (Umbelliferae). Annalen des Naturhistorischen Museums in Wien. Serie B für Botanik und Zoologie 112: 501-501.

Ghahremaninejad F, Nejad Falatoury A, Mahmoodi M, Fereidounfar S, et al. (2013). Plant chromosome book of Iran. Tehran: House of Biology Press.

Hipp AL, Hall JC and Sytsma KJ (2004). Congruence versus phylogenetic accuracy: revisiting the incongruence length difference test. Syst. Biol. 53: 81-89. http://dx.doi.org/10.1080/10635150490264752

Khajepiri M, Ghahremaninejad F and Mozaffarian V (2010). Fruit anatomy of the genus Pimpinella L. (Apiaceae) in Iran. Flora 205: 344-356. http://dx.doi.org/10.1016/j.flora.2009.12.030

Kimura M (1980). A simple method for estimating evolutionary rates of base substitutions through comparative studies of nucleotide sequences. J. Mol. Evol. 16: 111-120. http://dx.doi.org/10.1007/BF01731581

Logacheva MD, Valiejo-Roman CM and Pimenov MG (2008). ITS phylogeny of West Asian Heracleum species and related taxa of Umbelliferae-Tordylieae WDJ Koch, with notes on evolution of their psbA-trnH sequences. Plant Syst. Evol. 270: 139-157. http://dx.doi.org/10.1007/s00606-007-0619-x

Maddison WP and Knowles LL (2006). Inferring phylogeny despite incomplete lineage sorting. Syst. Biol. 55: 21-30. http://dx.doi.org/10.1080/10635150500354928

Magee AR, van Wyk BE, Tilney PM and Downie SR (2010). Phylogenetic position of African and Malagasy Pimpinella species and related genera (Apiaceae, Pimpinelleae). Plant Syst. Evol. 288: 201-211. http://dx.doi.org/10.1007/ s00606-010-0325-y

Matevski V (2005). Pimpinella L. In: The flora of the Republic of Macedonia 1(6) (Micevski K. eds.). Skopje: Macedonian Academy of Science and Arts. 1564-1567.

Matthews VA (1972). Pimpinella L. In: Flora of Turkey and the East Aegean Islands, vol. 4 (Davis PH. eds.). Edinburgh: Edinburgh University Press. 352-364.

Mozaffarian V (2007). Flora of Iran 54. (Assadi M, Maassoumi AA., KhatamsazM. eds.). Tehran: Research Institute of Forests and Rangelands.

Page RDM (2001). Division of Environmental and Evolutionary Biology, University of Glasgow, Glasgow, UK.

Pimenov MG and Leonov MV (1993). The genera of the Umbelliferae: a nomenclator. Royal Botanic Gardens, Kew.

Pimenov MG, Dauschkevich JV, Vasil'eva MG, et al. (1996). Mediterranean chromosome number reports 6. Fl. Medit. 6: 288-307.

Posada D and Crandall KA (1998). MODELTEST: testing the model of DNA substitution. Bioinformatics 14: 817-818. http://dx.doi.org/10.1093/bioinformatics/14.9.817

Pu FT and Watson MF (2005). Flora of China Pimpinella L. (Wu ZY, Raven PH. eds.). Science Press, Missouri Botanical Garden Press. 14: 93-104.

Ronquist F and Huelsenbeck JP (2003). MrBayes 3: Bayesian phylogenetic inference under mixed models. Bioinformatics 19: 1572-1574. http://dx.doi.org/10.1093/bioinformatics/btg180

Rostovtseva TS (1982). Chromosome numbers of some species of the family apiaceae. III. Bot. Zhurn. SSSR 67: 206-210.

Shimodaira H and Hasegawa M (1999). Multiple comparisons of log-likelihoods with applications to phylogenetic inference. Mol. Biol. Evol. 16: 1114-1116. http://dx.doi.org/10.1093/oxfordjournals.molbev.a026201

Shner JV, Pimenov MG, Kljuykov EV, Alexeeva TV, et al. (2004). Chromosome numbers in the Iranian Umbelliferae. Chr. Sci. 8: 1-9.

Simmons MP and Ochoterena H (2000). Gaps as characters in sequence-based phylogenetic analyses. Syst. Biol. 49: 369381. http://dx.doi.org/10.1093/sysbio/49.2.369

Spalik K and Downie SR (2006). The evolutionary history of Sium sensu lato (Apiaceae): dispersal, vicariance, and domestication as inferred from ITS rDNA phylogeny. Am. J. Bot. 93: 747-761. http://dx.doi.org/10.3732/ajb.93.5.747

Spalik K and Downie SR (2007). Intercontinental disjunctions in Cryptotaenia (Apiaceae, Oenantheae): an appraisal using molecular data. J. Biogeogr. 34: 2039-2054. http://dx.doi.org/10.1111/j.1365-2699.2007.01752.x

Swofford DL (2002). PAUP*: phylogenetic analysis using parsimony (*and other methods) Sinauer. Sunderland, Massachusetts, USA.

Genetics and Molecular Research 15 (4): gmr15048767 
Tabanca N, Douglas AW, Bedir E, Dayan FE, et al. (2005). Patterns of essential oil relationships in Pimpinella (Umbelliferae) based on phylogenetic relationships using nuclear and chloroplast sequences. Plant Genet. Resour. 3: 149-169. http://dx.doi.org/10.1079/PGR200573

Valiejo-Roman CM, Shneyer VS, Samigullin TH, Terentieva EI, et al. (2006a). An attempt to clarify taxonomic relationships in Verwandtschaftskreis der Gattung Ligusticum (Umbelliferae-Apioideae) by molecular analysis. Plant Syst. Evol. 257: 25-43. http://dx.doi.org/10.1007/s00606-005-0383-8

Velayos M (2003). Pimpinella L. S. Castroviejo \& al. (eds.) Flora Iberica 10: 181-191.

Wang ZX, Downie SR, Tan JB, Liao CY, et al. (2014). Molecular phylogenetics of Pimpinella and allied genera (Apiaceae), with emphasis on Chinese native species, inferred from nrDNA ITS and cpDNA intron sequence data. Nord. J. Bot. 32: 642-657. http://dx.doi.org/10.1111/j.1756-1051.2013.00343.x

Wolff H (1910). Umbelliferae-Apioideae-Bupleurum, Trinia et reliquae Ammineae heteroclitae: mit 155 Einzelbildern in 24 Figuren; ausgegeben am 2. August 1910. Engelmann.

Wolff H (1927). Umbelliferae-Apioideae-Ammineae-Carinae, Ammineae novemjugat. et gen. (Cryptotaeniopsis). Pflanzenr 90: 174-182.

Yurtseva OV and Tikhomirov VN (1998). Morphological diversity and taxonomy of the Pimpinella tragium VIll. group (Umbelliferae-Apioideae) in the Mediterranean. Feddes Repert. 109: 479-500. http://dx.doi.org/10.1002/ fedr.19981090703

Zakharova EA, Degtjareva GV and Pimenov MG (2012). Redefined generic limits of Carum (Umbelliferae, Apioideae) and new systematic placement of some of its taxa. Willdenowia 42: 149-168. http://dx.doi.org/10.3372/wi.42.42201

Zhou J, Peng H, Downie SR, Liu ZW, et al. (2008). A molecular phylogeny of Chinese Apiaceae subfamily Apioideae inferred from nuclear ribosomal DNA internal transcribed spacer sequences. Taxon 57: 402-416.

Zhou J, Gong X, Downie SR and Peng H (2009). Towards a more robust molecular phylogeny of Chinese Apiaceae subfamily Apioideae: additional evidence from nrDNA ITS and cpDNA intron (rpl16 and rps16) sequences. Mol. Phylogenet. Evol. 53: 56-68. http://dx.doi.org/10.1016/j.ympev.2009.05.029

\section{Supplementary material}

Table S1. Voucher information (or reference to voucher information) and GenBank accession No. for taxa used in the present study. A dash indicates that the region was not sampled. Voucher specimens are deposited in the following herbaria: TARI, Research Institute of Forests and Rangelands, Iran; T, Kharazmi University; VANF, Yüzüncü Yil University, Turkey. 